\title{
KONSEP RUANG TERBUKA PUBLIK MAHASISWA SEBAGAI PENGHUBUNG ANTAR UNIT DI UNIVERSITAS TANJUNGPURA
}

\author{
Yudi Purnomo; Mira S. Lubis; M. Nurhamsyah; Mustikawati
}

\author{
Program studi Arsitektur, Universitas, Tanjungpura, Indonesia \\ ud.ipolis@gmail.com
}

\begin{abstract}
ABSTRAK
Ruang publik merupakan wadah pemersatu atau sarana interaksi antar masyarakat yang berbeda dalam satu ruang. Konsep ruang publik yang dapat dimanfaatkan ruang sosial juga dapat dimiliki secara individu (private), seperti pusat perbelanjaan, restoran, kampus, dan lain-lain. Kampus merupakan ruang individu sekaligus ruang publik bagi pertukaran informasi (keilmuan), tempat pemenuhan kebutuhan psikologis (rekreasi) dan fungsi biologis (ruang terbuka hijau) yang dimanfaatkan oleh civitas akademika maupun masyarakat umum. Bagaimana ruang terbuka kampus khususnya di Universitas Tanjungpura dapat menjadi ruang publik merupakan rumusan permasalahan dalam tulisan ini. Teknik observasi, kuesioner dan pemetaan perilaku merupakan metode pengumpulan data penelitian. Hasil dari ketiga metode tersebut dianalisis menggunakan crosstab chi-square dan analisis diskriminan untuk mengidentifikasi ada atau tidaknya hubungan antara pemilihan ruang publik terhadap sifat responden dalam melihat ruang ruang publik serta untuk mengklasifikasikan preferensi responden terhadap komponen dan kriteria perancangan ruang publik. Hasil penelitian menyimpulkan bahwa rumusan kriteria perancangan ruang publik mahasiswa di Universitas Tanjungpura sangat tergantung kepada faktor seorang mahasiswa melihat lokasi atau tempat ruang tersebut. Faktor jenis kelamin, faktor sifat dan bentuk kegiatan, waktu dan lamanya berkegiatan, frekuensi melakukan kegiatan, teman, serta alasan menjadi faktor penentu dalam merumuskan konsep perancangan.
\end{abstract}

Kata Kunci: Ruang Publik, Universitas Tanjungpura, crosstab chi-square, analisis determinan

\begin{abstract}
.ABSTRACT
Public space is a communal area to accommodate interaction between different communities in one space. The concept of public space that can be utilized as social space can also be owned by individual party (private), such as shopping centers, restaurants, campuses, and others. The campus is a private space which is used as public space for the exchange of science information and an area to fulfillment the psychological and biological needs (recreation and green open spaces) that is used by the academic community and societies. The aim of this paper is to formulate concepts of open space in Tanjungpura university as a public space. This study use three techniques/methods of data collection, such as observation, questionnaire and a behavioral mapping. The results of these methods were analyzed by chi-square crosstab and discriminant analysis to identify whether there are any relationship between the selection of public space and the respondent preferences in viewing public space. Furthermore, the analysis also has a goal to classify the preference of respondents about components and criteria of the design of public space. This study concluded that the formulation of design criteria of public space for student in the Tanjungpura university is depend on the factors of the students itself in viewing the location of the space. The determining factors in formulating the design concept of the public open space are gender, the nature and kind of activity, duration of activities, frequency of activities, and partner in activities.
\end{abstract}

Keywords: Public Space, University of Tanjungpura, crosstab chi-square, analysis of the determinants

\section{Pendahuluan}

Ruang publik menawarkan peluang untuk menarik interaksi sosial masyarakat.
Bentuknya dalam bertemu masyarakat, saling mengenali, bertegur sapa, saling mengacuhkan satu sama lain atau bahkan konflik. Nilai-nilai sosial dari sebuah ruang 
Yudi Purnomo, dkk. "konsep ruang terbuka publik di Universitas Tanjungpura"

publik didasarkan pada kontribusi dari masing-masing individu kepada ruang tersebut dan kemungkinan akumulasi beberapa individu serta memori individu terhadap tempat tersebut (Dines and Cattle dalam Worpole \& Knox, 2007).

Pada masa lalu, studi konsep tentang ruang (terbuka) publik fokus pada tingkatan keruangan, khususnya aksesibilitas visual dan fisik, bentuk dan ukuran serta pembatas ruang (Sitte dan Zucker dalam Nathwutthikun, 2008). Konsep apa itu ruang publik telah berganti seiring waktu. Ruang publik secara tradisional dapat berupa jalan raya, pasar, taman, tempat bermain dan lainnya. Saat ini fokus konsep ruang publik menuju ke arah aspek estetik dan proporsi ruang terbuka. Di era modern, ruang publik dihasilkan sebagai alat untuk meningkatkan kualitas hidup. Lebih lanjut, konsep ruang publik juga merambah kepada ruang-ruang yang dimanfaatkan secara luas oleh masyarakat umum, namun dimiliki secara individu (baca: private). Contoh ruang tersebut adalah pusat-pusat perbelanjaan, restoran dan café, dan pusat-pusat penyelenggaraan pameran dan seni.

Kawasan sebuah perguruan tinggi (kampus) merupakan wilayah 'private' dengan fungsi pendidikan. Kampus juga dapat menjadi ruang 'publik' bagi pertukaran informasi keilmuan antar civitas akademika maupun civitas akademika dengan masyarakat luas dan masyarakat umum untuk berbagai kegiatan.

Universitas Tanjungpura (UNTAN) merupakan universitas negeri terbesar di Provinsi Kalimantan Barat, didirikan pada tanggal 20 Mei 1959 dengan luas lahan 274ha. Universitas Tanjungpura merupakan suatu kawasan multi building. Pemanfaatan lahan yang menyebar membuat penggunaan lahan menjadi tidak efisien. Ketidakefisienan tersebut menyebabkan pengawasan dan perawatan menjadi sulit untuk dilakukan dan menyebabkan antar civitas akademika tidak saling mengenal satu sama lain dan kemudian diperparah dengan munculnya konflik antar civitas akademika (pertikaian di tingkat mahasiswa) yang berlainan fakultas.

Konflik yang terjadi di dalam lingkungan kampus juga dapat terjadi oleh banyak fakultas. Persoalan pribadi hingga ego kelompok atau territorial seringkali memicu konflik. Ruang publik di dalam kampus menjadi tempat konflik dan bukan tidak mungkin memiliki kontribusi langsung maupun tidak langsung menjadi penyebab terjadinya konflik.

Berbagai fasilitas bersama yang ada seharusnya dapat menjadi fasilitas pendukung kegiatan yang relevan dengan kegiatan kampus dan diharapkan mampu untuk meminimalisir konflik. Fasilitas tersebut dapat berupa ruang terbuka seperti sirkulasi untuk transportasi, pedestrian, dan parkir, lapangan upacara, serta taman-taman maupun bangunan yang diperuntukkan untuk kepentingan umum. Saat ini sebaran fasilitas tersebut menjadi bagian dari 'teritori' fakultas yang kurang mendukung integrasi antar fakultas.

Kampus selain sebagai ruang privat juga harus mampu menjadi ruang publik bagi kepentingan pengembangan keilmuan. Untuk itulah diperlukan sebuah konsep ruang publik yang dapat menjadi penghubung antar unit dan antar civitas akademika.

\section{Permasalahan}

Permasalahan utama dalam merencanakan keberhasilan sebuah ruang publik adalah bagaimana ruang publik tersebut berhasil sebagai ruang sosial sekaligus berperan sebagai pembentuk citra sebuah kawasan, meningkatkan kualitas fisik dan sosial lingkungan, karena ruang publik merupakan tempat bertemu dan pusat dari berbagai aktivitas yang ada disekitarnya. Keberhasilan tersebut sangat tergantung kepada proses perencanaan yang berorientasi kepada penggunanya.

Preferensi mahasiswa sebagai pengguna ruang kampus menjadi penting untuk dikaji. Sehingga diharapkan ruang publik di kawasan kampus Universitas Tanjungpura dapat menjadi ruang pertukaran informasi (keilmuan) disamping sebagai tempat pertemuan secara fisik, tempat pemenuhan kebutuhan psikologis (rekreasi) dan fungsi biologis (ruang terbuka hijau).

\section{Ruang Terbuka Publik}

Menurut sifat kepemilikannya, ruang terbuka terbagi menjadi (Marcus \& Francis dalam Eriawan, 2003): (1) Ruang milik 
Yudi Purnomo, dkk. "konsep ruang terbuka publik di Universitas Tanjungpura"

publik atau yang bisa diakses oleh publik; (2) Ruang milik atau yang dikelola secara pribadi/swasta tapi bisa diakses oleh publik; (3) Ruang milik pribadi dan hanya bisa diakses oleh kelompok tertentu saja. Ruang terbuka publik adalah bentuk dasar dari ruang terbuka di luar bangunan, seperti nodes dan landmark yang menjadi alat navigasi di dalam kota, dapat digunakan oleh setiap orang dan memberi kesempatan untuk bermacam-macam kegiatan (Hakim dan Gilbert, 2010).

Sebagai tempat interaksi masyarakat, ruang publik juga berfungsi dalam menjaga dan meningkatkan kualitas kawasan perkotaan. Salah satu yang mengatur tentang kualitas kawasan perkotaan di Indonesia adalah Undang-Undang No.26 Tahun 2007 tentang Penataan Ruang, dimana dalam pasal 28 telah diatur tentang perlunya penyediaan Ruang Terbuka Hijau dan Ruang Terbuka Non Hijau. Selanjutnya di dalam Permen PU No.12 Tahun 2009 disebutkan bahwa secara umum ruang terbuka publik di perkotaan terdiri dari ruang terbuka hijau dan ruang terbuka non hijau, khususnya ditinjau dari sisi kepemilikan.

Tipologi Ruang Terbuka dapat diklasifikasikan sebagai berikut:

(1) Ruang Terbuka Non Hijau (Permen PU No.12/PRT/M/2009);

(b)Parkir; (c)Lapangan; (d)Tempat bermain dan rekreasi; (f)Pembatas (buffer); (g)Koridor.

(2)Ruang Terbuka Hijau (Permen PU No.5/PRT/M/2008); (a) Secara fisik; (b) Fungsi; (c) Struktur ruang; (d) Kepemilikan.

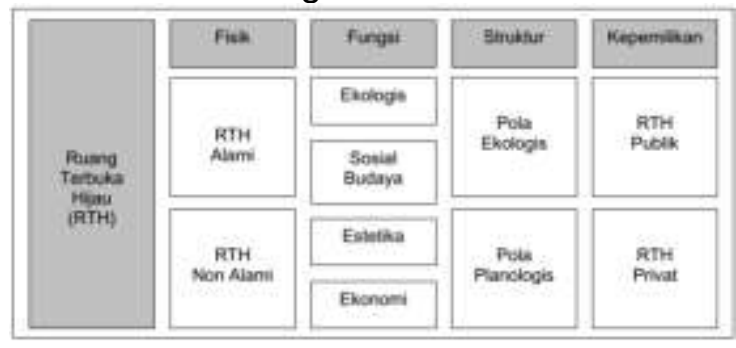

Sumber: Permen PUNo.5/PRT/M/2008 Gambar1: Tipologi RTH

Ruang publik yang ideal seharusnya memenuhi kriteria (Siahaan, 2010): (1) image and identity, berdasarkan sejarahnya; (2) Attraction and Destinations, memiliki tempat-tempat kecil yang di dalamnya memiliki suatu daya tarik; (3) Ketenangan (amenities, memiliki bentuk ketenangan yang membuat orang merasa nyaman; (4) Flexible Design, digunakan sepanjang hari, dari pagi, siang dan malam; (5) Seasonal Strategy, Keberhasilan ruang terbuka bukan hanya focus pada salah satu desain saja, atau pada strategi manajemennya. Tetapi dengan memberikan tampilan yang berubah-ubah yang berbeda dari satu musim ke musim lainnya; (6) Akses Ruang terbuka memiliki kedekatan dan kemantapan aksesibilitas, mudah dijangkau.

Komponen pembentuk taman sebagai ruang terbuka (Nasutiondalam Eriawan, 2003) terdiri dari :

(1) Unsur-unsur fisik, meliputi: (a) Unsur Dominasi, yaitu unsur-unsur berupa suatu bentuk fisik yang ada di dalam taman untuk mendefinisikan ruang tersebut; (b) Unsur Pelingkup, yaitu unsur berupa bentuk fisik yang membatasi taman; (c) Unsur Pengisi, yaitu unsur fisik utama yang mengisi taman; (d) Unsur pelengkap, yaitu unsur berupa bentuk fisik yang berfungsi mewadahi kebutuhan warga kota di sebuah taman.

(2) Unsur-unsur non fisik, meliputi: (a) Pasif, yaitu kegiatan yang secara umum dilakukan orang tanpa perlu bantuan orang lain untuk melakukannya atau tanpa perlu berpindah-pindah tempat; (b) Aktif, yaitu kegiatan yang secara umum dilakukan dengan berpindah-pindah tempat.

Konsep-konsep yang melandasi keinginan dan kepuasan pengguna dalam memanfatkan taman adalah (Gold dalam Eriawan, 2003): (1) Mengharapkan pengalaman yang menyenangkan dalam suatu taman kota. (2) Menyadari adanya 
Yudi Purnomo, dkk. "konsep ruang terbuka publik di Universitas Tanjungpura"

suatu range pilihan menyangkut bagaimana dan dimana mereka menggunakan waktu luangnya. (3) Memiliki keinginan sosial/psikologis yang harus bisa ditampung sebagai bagian dalam pemanfaatan taman. Sedangkan kualitas keinginan dan kepuasan pengguna taman terbagi dua (Gold dalam Eriawan, 2003), yaitu: (1) Kualitas Sumberdaya (Resource Quality), yaitu suatu ukuran objektif dari faktor atau kondisi pandangan pengguna terhadap elemen alamiah dan buatan atau fasilitas taman seperti pemandangan (scenery), vegetasi, perairan, toilet, meja bangku dsb. (b) Kualitas Pemanfaatan (Use Quality), yaitu ukuran objektif terhadap faktor atau kondisi pengguna sebagai sesuatu hambatan (negatif) atau keuntungan (positif) terhadap keinginan dan kepuasan mereka seperti terlalu ramai (overcrowding), bising, konflik, rasa takut, dan sebagainya.

Kualitas ruang juga dapat dilihat berdasarkan keberadaan nilai-nilai utama (primary values) dalam ruang publik (Carr dalam Eriawan, 2003), yaitu :

(1) Kenyamanan (comfort) yaitu ruang terbuka publik dalam peruntukannya harus bisa memenuhi berbagai kebutuhan dasar pengguna seperti tempat beristirahat, terlindung dari sengatan matahari, tempat berolahraga dan sebagainya;

(2) Relaksasi (relaxation) sebagaimana halnya kenyamanan merupakan suatu ukuran kepuasan psikologis.

(3) Hubungan pasif dengan lingkungan (passive engagement) dapat membawa suatu perasaan santai, tapi berbeda dengan relaksasi, kondisi ini memerlukan keterlibatan dengan suatu keadaan, namun keterlibatan ini bersifat pasif atau tidak langsung, seperti melihat-lihat, menonton suatu pertunjukan, dan sebagainya.

(4) Hubungan aktif dengan lingkungan (active engagement) merupakan keterlibatan yang lebih langsung dengan tempat dan orang-orang didalamnya. Seperti bercakap-cakap, berolahraga, melakukan suatu perayaan dan lain sebagainya.

(5) Kemudahan (accesible) terdiri dari tiga hal, yaitu : (a) Kemudahan fisik (physical acces), yaitu apakah ruang terbuka tersebut tersedia untuk publik, apakah ada batasan fisik pada ruang terbuka seperti pagar, gerbang atau penjaga gerbang atau harus melewati tangga untuk mencapai kawasan, yang berarti tidak terbuka bagi pengguna kursi roda, orang tua, dan sebagainya. (b) Kemudahan visual (visual acces), yaitu apakah pengguna dapat melihat kedalam ruang terbuka dari luar, apakah mereka tahu bahwa itu adalah ruang publik ketika mereka memasukinya dengan aman dan akan diterima. Pada beberapa orang, terutama orang tua (fragile elderly persons), ruang publik dengan terlalu banyak aktifitas, seperti bermain bola mungkin kurang mudah diterima dan menyebabkan mereka merasa tidak berhak memanfatkannya. (c) Kemudahan simbolis (symbolic acces), yaitu adanya elemen-elemen yang membuat orang-orang atau sebagian orang merasa tidak diterima pada ruang publik tersebut. Seperti keberadaan penjaga gerbang (satpam).

(6) Kebebasan bertindak (freedom of action), yaitu suatu nilai keterbukaan dari ruang publik dimana orang-orang berhak untuk menggunakan dan bertindak dalam memanfaatkan ruang secara bebas atau memakai fasilitas yang ada. Perbedaan kepentingan pada kelompok atau masyarakat yang beragam membuat kebebasan bagi suatu kelompok mengganggu kebebasan kelompok lainnya.

(7) Tuntutan/pernyataan (claim) terhadap ruang publik adalah hak seseorang untuk menentukan tindakan pada ruang yang ditempatinya, seperti duduk, berolahraga dan lainnya. Klaim terhadap ruang publik berada antara aksesibilitas dan kebebasan bertindak. Pengendalian terhadap pemanfaatan ruang publik kadang diperlukan bagi seseorang untuk mencapai tujuannya dalam ruang publik, tapi akan dapat mengganggu kebebasan yang lainnya. Seperti keberadaan tempat duduk yang bisa dipindah atau warungwarung $\mathrm{PKL}$ yang meng-klaim kawasannya sendiri dengan kebutuhan orang lain untuk melakukan aktifitas pada ruang yang sama. 
Yudi Purnomo, dkk. "konsep ruang terbuka publik di Universitas Tanjungpura"

(8) Kepemilikan dan pengaturan (ownership and disposisition) Ruang terbuka publik pada dasarnya adalah milik publik walaupun pengaturan terhadap ruang tersebut belum tentu dapat dilakukan oleh publik. Ada tiga tipe pengaturan yang berkaitan dengan kepemilikan bersama masyarakat, yaitu : (a) Akses terbatas dan digunakan bagi sekelompok kecil masyarakat penghuni sekitar; (b) Pengaturan dan kepemilikan tetap dimiliki oleh masyarakat sekitar yang terbuka bagi publik, tapi ditutup pada waktu-waktu tertentu dan terkadang dibatasi untuk penggunaan publik; (c) Kepemilikan oleh masyarakat dan dipergunakan selama 24 jam sehari untuk publik (totally open).

\section{Ruang Publik dalam Konteks Pengguna Ruang}

Mahasiswa adalah aktor utama yang akan menggunakan ruang publik di suatu perguruan tinggi disamping civitas akademika lainnya, seperti dosen, pegawai atau karyawan, maupun tenaga pendukung lainnya. Hal ini membawa dampak bahwa manusia sebagai pengguna ruang memiliki peran yang sangat besar dalam menentukan kualitas sebuah ruang.

Kebutuhan dasar manusia terdiri dari tiga hal (Robert Ardrey dalam Laurens, 2005), yaitu keamanan (security), simulasi (simulation), dan identitas (identity). Dasar kebutuhan ini dapat dipakai untuk mengetahui sejauh mana sebuah rancangan dapat memberikan kepuasan bagi pemenuhan kebutuhan manusia penggunanya. Sangat tidak mungkin menentukan kebutuhan dasar mana yang telah terpenuhi tanpa melakukan analisis intensif dan personal (Myhrum dalam Laurens,2005).

Seorang perancang lebih menyukai menekankan pentingnya activity setting (Randy Hester dalam Laurens, 2005). Hal ini bertolak belakang dengan pemakai yang lebih mempertimbangkan siapa saja orang yang akan memakai fasilitas atau dengan siapa ia akan bersosialisasi. Hal ini menunjukkan adanya perbedaan prioritas antara seorang perancang dan pemakai/pengguna ruang.

Perilaku spasial atau bagaimana orang menggunakan setting lingkungan adalah sesuatu yang dapat diamati. Terdapat dua perbedaan dalam memandang perilaku spasial (Laurens, 2005), yaitu:

(1) Perbedaan perilaku individu.Bentuk sosialisasi manusia berbeda, ditentukan oleh lingkungan geografis dan sosial ia dibesarkan. Mereka memiliki motivasi yang berbeda, melihat dan menggunakan lingkungan juga secara berbeda.

(2) Kompetensi individu dan kelompok.Dicetuskan oleh Powell Lawton dalam Laurens (2005) dan digunakan untuk membantu memahami kebutuhan lingkungan dari berbagai segmen, seperti usia.

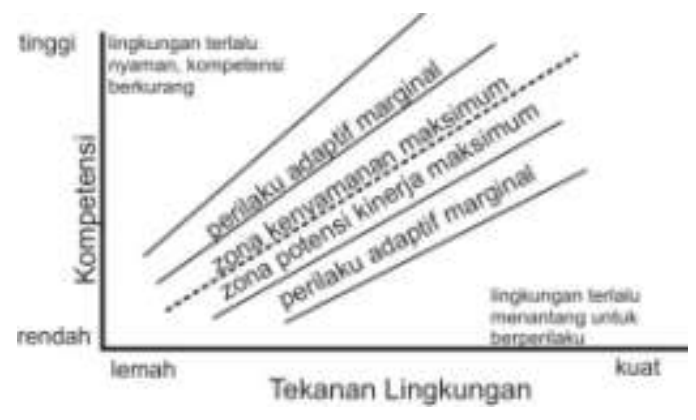

Sumber: Laurens, 2005

\section{Gambar2: Kompetensi Lingkungan}

Manusia memiliki kepribadian individual sebagaimana juga mahluk sosial, hidup bermasyarakat dalam suatu kolektivitas. Perilaku sosial manusia atau perilaku interpersonal meliputi hal-hal sebagai berikut (Laurens, 2005): (1) Ruang personal, berupa domain kecil sejauh jangkauan manusia yang dimiliki setiap orang; (2) Teritorialitas, yaitu kecenderungan untuk menguasai daerah 
Yudi Purnomo, dkk. "konsep ruang terbuka publik di Universitas Tanjungpura"

yang lebih luas bagi penggunaan oleh seseorang atau sekelompok pemakai atau bagi fungsi tertentu; (3) Kesesakan dan kepadatan, yaitu keadaan apabila ruang fisik yang tersedia sangat terbatas dibandingkan dengan jumlah penggunanya; (4) Privasi, sebagai usaha untuk mengoptimalkan pemenuhan kebutuhan sosial manusia.

Mendukung tujuan yang akan dicapai diperlukannya pembahasan tentang ruang personal dan teritorialitas. Terdapat tiga variabel yang mempengaruhi ruang personal (Halim, 2005):

(1) Faktor situasional; ketertarikan, kesamaan, dan jenis interaksi: (a) Perempuan merespon ketertarikan lebih secara spasial ketimbang lakilaki; (b) Jarak yang lebih dekat akan dipertahankan pada individu yang sama usia, ras, sub-budaya, agama, seks dan statusnya; (c) Feedback negative terhadap seseorang pada sebuah kelompok mengakibatkan jarak yang menjauh dari kelompok tersebut;

(2) Faktor situasi membuat kemarahan menciptakan jarak lebih dekat (untuk membalas) dan jarak lebih jauh (untuk proteksi);

(3) Faktor perbedaan individual; budaya dan ras, gender, usia, dan kepribadian; (a) Pada budaya dengan kontak indera tinggi, interaksi terjadi dalam jarak yang lebih dekat; (b) Perempuan berinteraksi pada jarak lebih dekat dengan yang disukainya, sedangkan laki-laki tidak membedakan ruang atas dasar kesukaannya. (c) Setelah enam tahun, semakin besar si anak (sampai dewasa), semakin besar jarak interpersonalnya; (d) Ciri-ciri kepribadian mewakili cara pandang seseorang terhadap dunia dan merefleksikan pembelajaran dan pengalaman.

(4) Faktor Fisikal Ruangan; (a) Kondisi gelap-terang ruang juga menentukan jarak ruang personal; (b) Jika orang tahu dirinya dapat menghindar, dia akan bisa puas dengan ruang personal kecil.

Dalam membentuk sebuah ruang fisikal terdapat 3 konsep dasar yang perlu diketahui, yaitu (Halim, 2005) : (1) Antropometri, adalah perhitungan dari ukuran-ukuran tubuh manusia. (2) Privasi, adalah mekanisme control individu dalam mengatur interaksi antar personal. (3) Proksemik adalah jarak antar manusia yang dianggap menyenangkan dalam suatu interaksi sosial.

Terdapat empat jarak prosemik yang menjelaskan jarak prosemik terhadap hubungan dan aktivitas serta kualitas sensorik (Halim, 2005), yaitu; (1) Jarak intim $(0-0,45 \mathrm{~m})$ hubungan dan aktivitasnya sesuai dengan kontak intim (sangat dekat);(2) Jarak pribadi $(0,45-1,2 \mathrm{~m})$ hubungan dan aktivitasnya sesuai dengan kontak antara teman dekat; (3) Jarak sosial (1,2-3,6m) hubungan dan aktivitasnya sesuai dengan kontak yang tidak pribadi dan kontak bisnis; (4) Jarak Publik (>3,6m) hubungan dan aktivitasnya sesuai dengan kontak formal antar individu (actor, politikus) dengan publik.

Sebelum merancang sebuah ruang untuk berbagai kegiatan manusia, kita harus memahami dengan cermat perilaku mereka. Ruang harus menjadi perhatian kita dan menjadi aspek paling berpengaruh pada tahap analisa dalam merancang penyelesaian sebuah masalah desain. Ruang dapat dibedakan menjadi ruang fisikal dan ruang psikososial. Ruang fisikal dibuat untuk mengakomodasi perilakuperilaku dasar manusia. Sedangkan ruang psikososial bisa hadir dalam bentuk fisik dan visual.

Konsep teritori menyatakan sebagai ruang yang dikuasai/dikendalikan oleh individu/kelompok dalam memuaskan motif/kebutuhan dan ditandai dengan konkrit/simbolik serta dipertahankan. Biasanya diartikan sebagai suatu set perilaku dan kognisi yang ditampilkan individu/kelompok berdasarkan pada pemahaman atas kepemilikan ruang fisik. Jenis teritori dapat dijelaskan sebagai berikut (Altman, 1975 dalam Halim, 2005):

(1) Primer(misal: rumah tinggal);

(2)Sekunder(misal: ruang kelas):

(3) Publik(misal: pantai)

Terdapat tiga pandangan territorial manusia (Brown dan Taylor dalam Halim, 2005), yaitu instinctive, learned dan interaksi keduanya. Menurut pandangan instinctive, tingkah laku territorial pada manusia dan hewan dipengaruhi oleh naluri, adanya dorongan untuk mengklaim 
Yudi Purnomo, dkk. "konsep ruang terbuka publik di Universitas Tanjungpura"

dan mempertahankan teritori, contohnya manusia dan hewan menandai tempat mereka dan menolak (kadang disertai ancaman) adanya pengganggu. Learned territorial menyatakan bahwa teritorialitas manusia merupakan hasil dari pengalaman masa lalu dan dari budaya.

\section{Gambaran Umum Universitas Tanjungpura (UNTAN)}

Universitas Tanjungpura merupakan universitas negeri terbesar di Provinsi Kalimantan Barat. Lokasi Universitas Tanjungpura berada di Kota Pontianak, tepatnya di wilayah Kecamatan Pontianak Tenggara. Universitas Tanjungpura didirikan pada tanggal 20 Mei 1959 sebagai perguruan tinggi swasta dengan nama Universitas Daya Nasional oleh Yayasan Perguruan Tinggi Daya Nasional. Tenaga pengajar pada waktu pertama kali berdiri adalah para sarjana dan sarjana muda yang ada di daerah Kalimantan Barat. Universitas Daya Nasional kemudian dinegerikan menjadi Universitas Negeri Pontianak (UNEP) berdasarkan SK Menteri PTIP Nomor 53 tahun 1963, tanggal 16 Mei 1963. Sesuai dengan perkembangan politik dan kenegaraan pada tahun 1965, UNEP berganti nama menjadi Universitas Dwikora pada tanggal 14 September 1965. Selanjutnya, dengan surat keputusan Presiden RI Nomor 171 tahun 1961 terhitung tanggal 15 Agustus 1967, ditetapkan kembali perubahan nama dari Universitas Dwikora menjadi Universitas Tanjungpura (UNTAN) yang akhirnya bertahan hingga sekarang. ${ }^{1}$

Mahasiswa yang mendaftar di Untan, dari tahun ke tahun terus meningkat. Pada awal tahun akademik 2011/2012 terdaftar sebanyak 20.276 orang mahasiswa (BAAK Untan, 2012). Sementara, jumlah mahasiswa program S-1 reguler hingga tahun ajaran 2011/2012 adalah 19.363orang. Jumlah tersebut tersebar di 121 program studi baik D3, S1 dan S2. Staf pengajar yang dimiliki oleh Untan sampai awal tahun 2012 berjumlah 964 orang dosen, dengan kualifikasi, 176 orang Doktor, 673 Orang Magister/master dan 115 orang sarjana.

\footnotetext{
${ }^{1}$ Disadur dari website Universitas Tanjungpura, http://www.untan.ac.id
}

Universitas Tanjungpura (UNTAN) merupakan suatu kawasan multi building. Kondisi wilayah terbangun terbentuk dari kondisi tapak serta bentuk dan kondisi fisik bangunan. Secara umum, zoning Untan terbagi atas masing-masing fakultas yang menyebar dari lahan yang berada di sebelah utara dan selatan JI A. Yani. Pada bagian utara Jl. A. Yani, terdapat satu fakultas yaitu Fakultas Kehutanan, Magister IImu Sosial, Magister Ekonomi dan Magister Hukum, Pusat Penelitian, PKM, Auditorium, KOPMA, kantin, fasilitas olahraga serta berbagai fasilitas umum lainnya. Sedangkan pada bagian selatan terdapat Fakultas Teknik, Fakultas Pertanian, FISIPOL, Fakultas Hukum, Fakultas Ekonomi, FKIP, Fakultas MIPA, Fakultas Kedokteran, rektorat, Rusunawa, Perpustakaan, UPT Bahasa dan PUSKOM. Sementara itu, fasilitas-fasilitas bersama tidak berada pada zona yang sama, tapi berada di sepanjang Koridor utama pada bagian utara Jl. A. Yani.

Kondisi ini mengakibatkan koordinasi dan pengawasan antara rektorat dengan seluruh fakultas maupun antar fakultas menjadi sangat tidak efisien. Akibat lainnya adalah antar civitas akademika tidak saling mengenal satu sama lain. Kondisi ini menjadi parah dengan seringnya konflik yang muncul antar civitas akademika yang berlainan fakultas. Bahkan pada tingkat mahasiswa, konflik ini tak jarang berakhir dengan pertikaian.

Luas kawasan Untan \pm 274 ha yang terbelah dua oleh Jalan Ahmad Yani, yaitu bagian utara seluas kurang lebih 173,944 ha dan bagian selatan seluas kurang lebih 100,056 ha. Kondisi ini menyebabkan kawasan atau Kampus Untan memiliki dua pintu masuk utama yaitu akses dari Jalan Imam Bonjol pada bagian utara dan akses dari Jalan Ahmad Yani pada bagian tengah kawasan.

$\begin{array}{cc} & \text { Khususnya di wilayah bagian selatan } \\ \text { persil Universitas Tanjungpura, }\end{array}$ pemanfaatan lahan didominasi oleh ruang terbuka (void). Fisik bangunan atau angka ketertutupan lahan oleh bangunan sangat kecil. Kondisi ini tentunya merupakan sebuah potensi bagi terbentuknya ruangruang terbuka yang dapat menunjang kegiatan akademis di lingkungan Untan maupun memiliki nilai ekologis bagi 
Yudi Purnomo, dkk. "konsep ruang terbuka publik di Universitas Tanjungpura"

lingkungan dan kota. Untuk menunjang kegiatan akademis, ruang terbuka yang cukup luas tersebut dapat dimanfaatkan sebagai taman aktif maupun pasif, seperti tempat belajar (mengajar), relaksasi, olahraga dan lain sebagainya. Hal ini dapat terlihat pada Gambar 3 di bawah ini.

Dalam gambar tersebut dapat
dijelaskan secara umum bahwa
penggunaan ruang terbuka di lingkungan Untan masih belum optimal. Sebagian ruang terbuka yang sudah direncanakan peruntukkannya sebagai ruang parkir bagi civitas akademika dan ditempatkan di tiap unit kerja. Aktivitas mahasiswa khususnya di ruang luar, tidak terlinat kecuali pada beberapa titik ruang seperti gazebo yang ada di tiap unit fakultas, halte, dan ruang terbuka yang memiliki perkerasan.

Pada sore hari dan akhir minggu (sabtu dan minggu) ruang terbuka di lingkungan Universitas Tanjungpura dipergunakan untuk kegiatan olahraga dan rekreasi bagi sebagian orang. Bukan saja mahasiswa namun warga kota baik priawanita dan segala usia sering memanfaatkan ruang terbuka tersebut. Ruang terbuka dimaksud adalah Taman Untan di depan Bangunan Gedung Magister Teknik dan Taman Untan di depan Bangunan Gedung Rektorat.

\section{(2) \\ Sumber: BAPSI Untan, 2012 \\ Gambar3: Pemanfaatan Lahan Untan}

\section{Analisis Dan Hasil Penelitian}

Responden penelitian diambil
berdasarkan sampel dari populasi
mahasiswa di Universitas Tanjungpura. Sampel yang diambil dalam penelitian ini menggunakan tingkat keandalan 95\% dengan galat pendugaan 0,1 . Ketentuan ini menghasilkan nilai sample sebanyak 96 mahasiswa dari jumlah populasi 20.276 orang mahasiswa. Selanjutnya sample diproporsionalkan dengan jumlah mahasiswa masing-masing fakultas.

Karakteristik responden dalam penelitian ini dapat dikategorikan dalam empat kelompok. Keempat kelompok tersebut adalah asal fakultas, usia, jenis kelamin dan semester perkuliahan yang sudah ditempuh. Untuk asal fakultas, komposisi responden sesuai dengan jumlah sampel yang diambil. Fakultas IImu Keguruan dan IImu Pendidikan (FKIP) merupakan responden terbesar dengan 26 orang mahasiswa, hal ini disebabkan jumlah mahasiswa FKIP juga merupakan mahasiswa terbanyak di Universitas Tanjungpura (27\%) dari jumlah seluruh mahasiswa untan. Sedangkan Fakultas Kehutanan,3orang mahasiswa dikarenakan mahasiswa Fakultas Kehutanan hanya 3\%. Mahasiswa Laki-laki merupakan responden terbanyak daripada responden wanita. Selisih jumlah responden pria dan wanita tidak terlalu jauh, yaitu hanya selisih dua orang mahasiswa. Sehingga dalam penelitian ini dianggap suara atau pendapat gender dianggap seimbang.

Rata-rata, mahasiswa yang menjadi responden adalah mahasiswa yang sedang menempuh perkuliahan pada semester satu dengan total 30 orang responden (31,5\%). Selanjutnya diikuti mahasiswa semester $3(26,04 \%)$, semester $5(17,70 \%)$ 
Yudi Purnomo, dkk. "konsep ruang terbuka publik di Universitas Tanjungpura"

dan semester 7 (9\%). Mahasiswa semester terakhir, yaitu di atas semester 7 terdapat 15 orang mahasiswa (15,63\%). Dari data ini juga terlihat bahwa sebaran responden juga merata di tiap tingkat/jenjang semester perkuliahan yang ditempuh.

\section{Preferensi Mahasiswa sebagai Pengguna Ruang}

Sesuai dengan tujuan utama penelitian adalah menghasilkan konsep ruang terbuka publik mahasiswa sebagai penghubung antar unit di Universitas Tanjungpura, maka perlu dilakukan penilaian kelayakan dari sisi preferensi mahasiswa. Tingkat kenyamanan dari sisi preferensi mahasiswa dalam hal bersosialisasi dan beraktifitas dengan civitas akademika lainnya menjadi syarat diadakannya ruang publik sebagai penghubung antar unit kegiatan.

Berdasarkan hasil analisis yang dilakukan terhadap tingkat kenyamanan tersebut, diperoleh hasil bahwa rata-rata mahasiswa setuju dan merasa nyaman bila mereka menggunakan ruang terbuka bersama dengan mahasiswa atau civitas akademika lainnya. Namun yang menjadi catatan dalam penelitian ini adalah bahwa ruang terbuka dimaksud tidak terlalu jauh dari tempat mahasiswa tersebut belajar, dalam hal ini adalah fakultas, karena kekhawatiran bila ruang tersebut jauh akan dikuasai oleh individu atau kelompok tertentu.

Berdasarkan preferensi responden terhadap kuesioner yang disebarkan, dapat diperoleh beberapa hasil analisis, diantaranya adalah lokasi yang dipilih sebagai ruang publik mahasiswa di Untan. Lokasi yang paling banyak dipilih oleh responden adalah ruang publik yang berada di depan Rektorat.

Tabel 1: Tingkat kenyamanan penggunaan ruang terbuka sebagai ruang publik



Tabel 2: Analisis Deskriptif Frekuensi Pemilihan Lokasi Ruang Terbuka di Untan

\begin{tabular}{|c|c|c|c|c|c|}
\hline \multicolumn{2}{|c|}{} & $\begin{array}{c}\text { Di Antara } \\
\text { Fakultas Teknik } \\
\text { dan Pertanian }\end{array}$ & $\begin{array}{c}\text { Di } \\
\text { Depan } \\
\text { Magister } \\
\text { Teknik }\end{array}$ & $\begin{array}{c}\text { Di Depan } \\
\text { Rektorat }\end{array}$ & Lain-Lain \\
\hline \multirow{2}{*}{$\mathrm{N}$} & Valid & 94,00 & 93,00 & 94,00 & 7,00 \\
\cline { 2 - 6 } & Missing & 2 & 3 & 2 & 89 \\
\hline \multicolumn{2}{|c|}{ Mean } & 2,33 & 2,83 & $\mathbf{3 , 8 3}$ & 4,57 \\
\hline \multicolumn{4}{|c}{ Sumber: Analisis, 2013} \\
\end{tabular}

Letak taman ini berada pada posisi strategis yang menghubungkan beberapa unit kerja di lingkungan Universitas Tanjungpura. Diantara unit kerja yang dihubungkan oleh taman ini adalah Gedung Rektorat Untan, Fakultas MIPA, Fakultas Teknik, Fakultas Pertanian, Fakultas IImu Sosial dan IImu Politik, serta Fakultas Hukum dan Fakultas Keguruan dan IImu Pendidikan. Gambar 4 di bawah ini menjelaskan kondisi tersebut di atas.
Mengetahui variabel sangat diperlukan dalam merumuskan konsep perancangan ruang ini. Variabel perancangan yang terkait dan diperlukan antara lain yaitu variabel sifat dan kegiatan responden, seperti asal fakultas, kelompok usia, jenis kelamin, pilihan kawasan eksisting yang menarik, semester perkuliahan yang sedang ditempuh, alasan beraktifitas dan pilihan kegiatan, frekuensi kunjungan serta dengan siapa mahasiswa biasanya mengunjungi taman tersebut. 


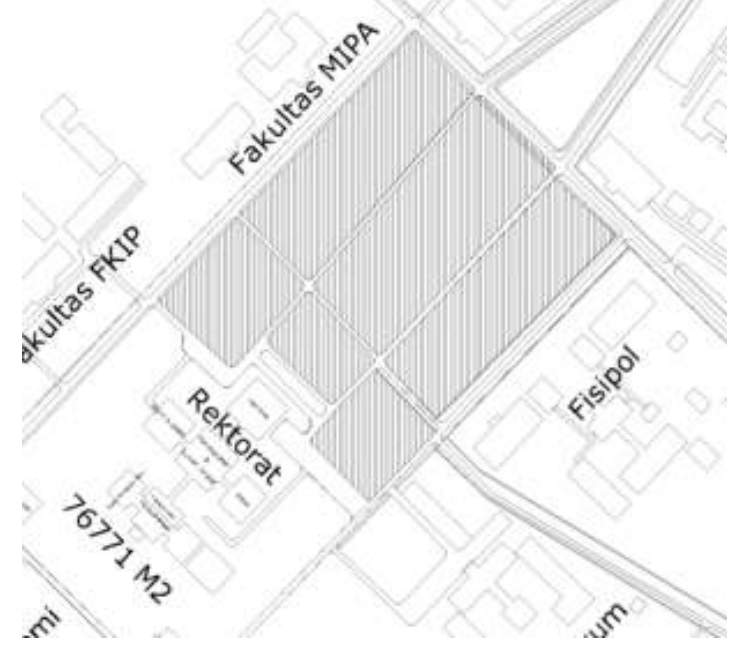

Sumber: Untan, 2012

\section{Gambar4: Ruang Publik di depan Rektorat Untan}

Berdasarkan hasil olahan statistik menggunakan crosstab chi-square, diperoleh hubungan antara variabel sifat dan kegiatan responden dalam memilih lokasi ruang terbuka publik di Untan (lihat Tabel 3). Hasil analisis mengindikasikan bahwa ketika mahasiswa memilih lokasi ruang publik/taman di lingkungan Untan sangat dipengaruhi oleh faktor jenis kelamin, namun tidak dipengaruhi oleh usia, asal fakultas, maupun semester yang sedang ditempuh. Fakta lainnya adalah bahwa Alasan berkunjung, kegiatan yang dilakukan, frekuensi, teman saat berkunjung, waktu kunjungan, dan lama kunjungan mempengaruhi seorang mahasiswa memilih ruang publik mahasiswa.

Table 3: Hubungan antara Variabel Sifat dan Kegiatan Responden dalam Memilih Lokasi Ruang Publik di Untan

\begin{tabular}{|c|c|c|}
\hline No & Variabel Penelitian & $\begin{array}{l}\text { Ada/Tidaknya } \\
\text { Hubungan }\end{array}$ \\
\hline 1 & Fakultas & Tidak \\
\hline 2 & Kelompok usia & Tidak \\
\hline 3 & Jenis Kelamin & Ada \\
\hline 4 & Kawasan menarik di Untan & Tidak \\
\hline 5 & Semester & Tidak \\
\hline \multirow[t]{4}{*}{6} & Alasan mengunjungi ruang publik kampus & \\
\hline & a. Sengaja datang karena ada sesuatu yang ingin & Ada \\
\hline & b. Sekedar mampir/kebetulan lewat & Tidak \\
\hline & c.lain-lain & Tidak \\
\hline 7 & $\begin{array}{l}\text { Kegiatan yang dilakukan ketika mengunjungi ruang publik kampus (Berbincang-bincang bersama } \\
\text { teman, Mengisi waktu senggang, Membaca buku, Mencari inspirasi, Mengerjakan tugas, Istirahat, } \\
\text { Melihat pemandangan yang ada) }\end{array}$ & Ada \\
\hline 8 & Frekuensi mengunjungi ruang publik kampus (3 kali seminggu, 1-2 kali sebulan, lain-lain) & Ada \\
\hline 9 & $\begin{array}{l}\text { Teman datang ke ruang publik Kampus (sendiri, teman satu fakultas, teman lain fakultas, dosen, lain- } \\
\text { lain) }\end{array}$ & Ada \\
\hline \multirow{2}{*}{10} & Waktu yang disukai untuk datang ke ruang publik kampus (pagi, sore, malam) & Ada \\
\hline & Waktu yang disukai untuk datang ke ruang publik kampus(siang) & Tidak \\
\hline 11 & $\begin{array}{l}\text { Waktu mengunjungi ruang publik kampus (akhir minggu, hari biasa jam kuliah, hari biasa disela-sela } \\
\text { kuliah) }\end{array}$ & Ada \\
\hline
\end{tabular}


Yudi Purnomo, dkk. "konsep ruang terbuka publik di Universitas Tanjungpura"

\begin{tabular}{|l|l|c|}
\hline No & \multicolumn{1}{|c|}{ Variabel Penelitian } & $\begin{array}{c}\text { Ada/Tidaknya } \\
\text { Hubungan }\end{array}$ \\
\hline \multirow{2}{*}{12} & Lama waktu kunjungan di ruang publik kampus (<1 jam, 1-2 jam, 2-3 jam) & Ada \\
\cline { 2 - 3 } & Lama waktu kunjungan di ruang publik kampus (>3 jam) & Tidak \\
\hline \multirow{2}{*}{13} & Ruang publik kampus yang sering dikunjungi (semua alternatif lokasi) & Tidak \\
\hline \multirow{2}{*}{14} & Bentuk aktivitas/kegiatan yang diinginkan (seni, sosial, olahraga) & Ada \\
\cline { 2 - 3 } & Bentuk aktivitas/kegiatan yang diinginkan (Demonstrasi mahasiswa, lain-lain) & Tidak \\
\hline
\end{tabular}

Sumber: Analisis, 2013

Dari tabel di atas dapat ditarik kesimpulan bahwa jenis kelamin, alasan berkegiatan di ruang publik, jenis kegiatan, waktu berkegiatan dan teman berkegiatan akan mempengaruhi konsep perancangan yang akan diterapkan pada rancangan.
Faktor-faktor lainnya yang tidak ada hubungan dianggap dapat diabaikan dalam merumuskan konsep perancangan, karena dianggap tidak terlalu mempengaruhi alasan mahasiswa memilih ruang tersebut.

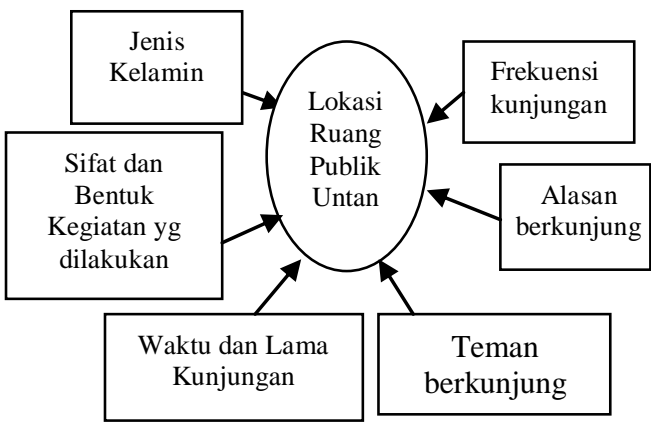

Sumber: Analisis, 2013

Gambar 5: Hubungan Pemilihan Lokasi dan Sifat dan Kegiatan Responden

\section{Konsep Ruang Publik Mahasiswa}

Faktor-faktor yang mempengaruhi responden dalam memilih lokasi ruang publik dianalisis untuk melihat klasifikasi faktor tersebut terhadap preferensi konsep perancangan. Cara analisis yang digunakan adalah analisis diskriminan. Faktor-faktor yang dianalisis dikelompokkan menjadi tiga kelompok, yaitu faktor gender, kegiatan yang dilakukan, serta alasan berkegiatan di ruang publik. Sedangkan faktor lainnya dimasukkan ke dalam bagian dari konsep perancangan.

Berdasarkan hasil analisis diperoleh kesimpulan bahwa, terdapat beberapa perbedaan konsep perancangan yang diinginkan oleh mahasiswa pria dan wanita. Mahasiswa pria dan wanita cenderung sama memilih konsep peneduh ruang publik, perabot, fasilitas yang diinginkan, serta tingkat kenyamanan bila ruang publik dimasuki oleh kelompok diluar kelompoknya, maupun duduk bersama lain usia dan gender.
Secara umum mahasiswa pria untuk konsep pembatas ruang publik hanya menginginkan pepohonan disusun membuat suatu pembatas antara ruang publik dan ruang lain yang ada disekitarnya.Sedangkan mahasiswa wanita cenderung lebih spesifik dibandingkan pria, seperti menambahkan dinding dan lantai yang terbuat dari bahan alami dan kombinasi. Jarak duduk nyaman bagi mahasiswa pria juga terdefinisi dengan jarak yang intim, sedangkan wanita tidak dapat terdefinisikan atau cenderung tidak memilih. Komposisi duduk yang disukai juga terdapat dua persamaan yaitu memilih duduk bersebelahan dan berkelompok berhadapan. Namun terdapat perbedaan antara mahasiswa pria dan wanita, dimana wanita cenderung juga menginginkan duduk berhadapan sedangkan pria tidak.

Konsep perancangan ruang publik berdasarkan kegiatan yang dilakukan diruang publik kampus diklasifikasikan menjadi 7 kelompok, yaitu berbincangbincang bersama teman, mengisi waktu senggang, membaca buku, mencari inspirasi, mengerjakan tugas, istirahat dan 
Yudi Purnomo, dkk. "konsep ruang terbuka publik di Universitas Tanjungpura"

melihat pemandangan yang ada. Ketujuh kelompok kegiatan yang ada memiliki konsep yang sama untuk peneduh ruang, seperti pohon dengan tajuk peneduh dan ruang yang memiliki atap/payung transparan. Persamaan lainnya adalah pada konsep pembatas ruang yang diinginkan, konsep perabotan yang dinginkan, fasilitas, serta lebih cenderung menerima mahasiswa dari kelompok lain untuk bersama-sama beraktifitas di ruang publik.

Walaupun banyak persamaan, ternyata terdapat beberapa perbedaan dilihat dari faktor. Perbedaan tersebut terletak dikegiatan membaca buku yang cenderung membutuhkan ruang yang lebih intim namun tidak menginginkan duduk berkelompok bersebelahan. Tidak menginginkan duduk berkelompok bersebalahan juga menjadi preferensi bagi kegiatan mengerjakan tugas. Kegiatan membaca buku yang cenderung merasa nyaman memasuki ruang publik yang jauh atau di luar dari ruang fakultas tempat ia belajar. Hal ini tidak dijumpai pada kegiatan lain. Kelompok kegiatan istirahat makan juga tidak menyetujui beraktifitas bersama civitas akademika lainnya.

Konsep perancangan ruang publik juga dapat dirancang dengan mempertimbangkan alasan seseorang mahasiswa mengunjungi ruang publik. Rata-rata responden mengatakan bahwa alasan berkunjung adalah sengaja datang karena ada sesuatu yang ingin dilakukan. Dengan alasan tersebut, maka konsep perancangan yang dapat diterapkan sebagaimana terdapat dalam tabel di bawah ini. Secara garis besar konsep hampir sama dengan faktor kegiatan, hanya saja secara spesifik, mahasiswa yang sengaja datang karena ada sesuatu yang ingin dilakukan cenderung memilih ruang publik yang dekat dengan tempat ia belajar.

Table 4: Konsep Perancangan Ruang Publik Berdasarkan Gender

\begin{tabular}{|c|c|c|c|}
\hline NO & KONSEP PERANCANGAN & PRIA & WANITA \\
\hline 1 & Konsep peneduh ruang publik kampus yang diinginkan & & \\
\hline a & Terbuka dengan tajuk pohon sebagai peneduh & $\mathrm{v}$ & $\mathrm{v}$ \\
\hline $\mathrm{b}$ & Beratap (berupa paying-payung atap transparan, dll) & $\mathrm{v}$ & $\mathrm{v}$ \\
\hline c & Lain-lain & $\mathrm{v}$ & $\mathrm{v}$ \\
\hline 2 & Konsep pembatas ruang publik yang diinginkan & & \\
\hline a & $\begin{array}{l}\text { Pepohonan disusun yang membuat suatu pembatas antara ruang publik dan ruang } \\
\text { lain yang ada disekitarnya }\end{array}$ & $\mathrm{v}$ & v \\
\hline $\mathrm{b}$ & Dinding dan lantai yang dibuat dari batu-batuan, pasir, dan batu bata & & $v$ \\
\hline c & Dinding dan lantai yang dibuat dari bahan kombinasi (beton dan plywood/kayu) & & v \\
\hline 3 & Konsep perabotan ruang publik yang diinginkan & & \\
\hline a & Memiliki meja, kursi, lampu penerangan, payung peneduh & $\mathrm{v}$ & v \\
\hline b & Lain-lain, sebutkan & $\mathrm{v}$ & $\mathrm{v}$ \\
\hline 4 & Jarak yang dibutuhkan untuk merasa nyaman & & \\
\hline a & Jarak $0-0,45 \mathrm{~m}$ & $\mathrm{v}$ & \\
\hline 5 & Konsep posisi duduk yang disukai & & \\
\hline a & Duduk Berdua berhadapan & & $\mathrm{v}$ \\
\hline b & Duduk Berdua bersebelahan & $\mathrm{v}$ & v \\
\hline c & Berkelompok berhadapan & $\mathrm{v}$ & v \\
\hline 6 & Fasilitas yang masih dirasakan kurang di ruang publik kampus saat ini & & \\
\hline a & Pohon-pohon peneduh & $\mathrm{v}$ & $\mathrm{v}$ \\
\hline b & WC umum & v & v \\
\hline c & Telepon umum & $\mathrm{v}$ & v \\
\hline$d$ & Tong sampah & $\mathrm{v}$ & v \\
\hline e & Tempat duduk & v & v \\
\hline$f$ & Musholla & $\mathrm{v}$ & $\mathrm{v}$ \\
\hline g & Jalur Pedestrian/pejalan kaki & $\mathrm{v}$ & $v$ \\
\hline
\end{tabular}


Yudi Purnomo, dkk. "konsep ruang terbuka publik di Universitas Tanjungpura"

\begin{tabular}{|c|c|c|c|}
\hline NO & KONSEP PERANCANGAN & PRIA & WANITA \\
\hline $\mathrm{h}$ & Parkir & $\mathrm{v}$ & $\mathrm{v}$ \\
\hline $\mathrm{i}$ & Drainase (saluran air) & $v$ & $\mathrm{v}$ \\
\hline j & Lain-lain & $v$ & $\mathrm{v}$ \\
\hline 7 & Setuju beraktivitas di ruang publik baru bersama civitas akademika dari fakultas lain & $\mathrm{v}$ & v \\
\hline 8 & $\begin{array}{l}\text { Merasa nyaman apabila ruang publik dapat digunakan oleh semua civitas akademika } \\
\text { yang ada di Universitas Tanjungpura }\end{array}$ & $v$ & $v$ \\
\hline 9 & Merasa nyaman duduk disebelah orang yang berbeda jenis kelamin & $v$ & $v$ \\
\hline 10 & $\begin{array}{l}\text { Merasa nyaman duduk di sebelah orang yang memiliki perbedaan umum (senior, } \\
\text { jenior, dosen) }\end{array}$ & $\mathrm{v}$ & $v$ \\
\hline
\end{tabular}

Sumber: Analisis, 2013

\section{Kesimpulan}

Secara garis besar penelitian ini menghasilkan konsep bahwa sebuah ruang terbuka publik sebagai sarana penghubung antar unit di Universitas Tanjungpura sangat mungkin untuk direalisasikan. Hal ini mengingat rata-rata responden merasa nyaman untuk beraktifitas bersama dengan mahasiswa lain yang berasal dari fakultas lainnya, usia dan gender yang berbeda. Namun demikian konsep perancangan yang akan diterapkan tetap mengacu kepada faktor-faktor yang telah diuraikan dalam bab sebelumnya.

Hasil penelitian juga menghasilkan kesimpulan bahwa konsep perancangan ruang publik mahasiswa sebagai penghubung antar unit di Universitas Tanjungpura sangat tergantung kepada faktor seorang mahasiswa melihat lokasi atau tempat ruang tersebut. Faktor jenis kelamin, faktor sifat dan bentuk kegiatan, waktu dan lamanya berkegiatan, frekuensi melakukan kegiatan, teman, serta alasan menjadi faktor penentu dalam merumuskan konsep perancangan.

\section{Daftar Pustaka}

---. 1991. Teori Perancangan Urban. Program Studi Perancangan Arsitektur Fakultas Pascasarjana ITB. Bandung

---. 2005. Peran Ruang Publik dalam Pengembangan Sektor Properti dan Kota. Sambutan Menteri Pekerjaan Umum dalam acara Seminar Nasional Araitektur Dalam Rangka Dies Natalis Ke-48 Universitas Diponegoro. Semarang

---. 2010. Jangan Terpancing Provokasi: Bentrok Dinihari, Polisi Lepaskan 21 Tembakan. Artikel dalam Pontianak Post Online tanggal 14 Maret 2010. Diakses 29 Mei

2012. http://www.pontianakpost.com/?mib=berita.d etail\&id=31280

---. 2011. Modul MAP. Program Magister Perencanaan Wilayah dan Kota ITB. Bandung

---. 2012. Undang Undang Nomor 12 Tahun 2012 tentang Pendidikan Tinggi. Pemerintah RI. Jakarta

---.n/a. Analisis Diskriminan. Diunduh Bulan Nopember $2013 \quad$ dari http://daps.bps.go.id/file_artikel/65/ANALISI S\%20DISKRIMINAN.pdf. BPS, Jakarta

---. 2011. Crosstab dan Chi-Square: Analisis Hubungan Antarvariabel Kategorikal. Bab

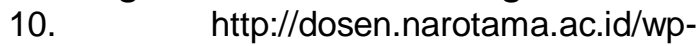
content/uploads//12/Mastering-SPSS-18.pdf

---. 1982.Keputusan Presiden Republik Indonesia Nomor 64 tahun 1982 tentang Susunan Organisasi Universitas Tanjungpura. Pemerintah RI. Jakarta

---. 2007.Peraturan Menteri Dalam Negeri Nomor 1 Tahun tentang Penataan Ruang Terbuka Hijau Kawasan Perkotaan. Kementerian Dalam Negeri. Jakarta

---. 2009.Peraturan Menteri Pekerjaan Umum Nomor 12 Tahun tentang Pedoman Penyediaan dan Pemanfaatan Ruang Terbuka Non Hijau di Wilayah Kota/Kawasan Perkotaan. Kementerian Pekerjaan Umum. Jakarta

---. 2008. Peraturan Menteri Pekerjaan Umum Nomor 5 Tahun tentang Pedoman Penyediaan dan Pemanfaatan Ruang Terbuka Hijau di Perkotaan. Kementerian Pekerjaan Umum. Jakarta

BPS Kota Pontianak. 2012. Kota Pontianak dalam Angka 2012. BPS Kota Pontianak. Pontianak

Eriawan, Tomi. 2003. Prinsip Perancangan Taman Kota dan Taman Bagian Wilayah Kota di Kota Bandung. Thesis pada Magister ITB. Bandung 
Yudi Purnomo, dkk. "konsep ruang terbuka publik di Universitas Tanjungpura"

Groat, Linda;DavidWang. 2002. Architectural Research Methods. John Wiley and Sons. New York

Halim, Deddy. 2005. Psikologi Arsitektur: Pengantar Kajian Lintas Disiplin. Gramedia Widiasarana Indonesia. Jakarta

Hardiman, F.Budi. 2010. Ruang Publik: melacak 'Partisipasi Demikratis' dari Polis sampai Cyberspace. Kanisius. Yogyakarta

Laurens, Joyce Marcella. 2005. Arsitektur dan Perilaku Manusia. PT. Grasindo. Jakarta

LeGates, Richard T; Stout, Frederic. 2000. The City Reader: Second Edition. Routledge. London and New York

Lynch, K. 1960. The Image of City. MIT Press. Cambridge, MA

Moleong, Lexy J. 2005. Metodologi Penelitian Kualitatif, Edisi Revisi.Rosda.Bandung

Nasution, S. 2011. Metode Research: Penelitian IImiah. Bumi Aksara. Jakarta

Nathiwutthikun, Kan, Wannasilpa Peerapan, Khaisri Paksukcharern. 2008. The Logic of Multi-Use of Public Open Spaces in Chiang Mai City. Nakhara Journal of Environmental Design and Planning, vol.4. Faculty of Architecture, Chulalongkorn University. Bangkok

Pusat Bahasa Departemen Pendidikan Nasional. 2008. Kamus Bahasa Indonesia.

Pusat Bahasa. Jakarta

Siahaan, James. 2010. Ruang Publik: Antara Harapan dan Kenyataan. Artikel online Bulletin Tata Ruang ISSN:1978-1571. Edisi
Juli-Agustus 2010. Diunduh bulan

Nopember 2013 dari

http://bulletin.penataanruang.net/index.asp?

mod=_fullart\&idart $=265$

Snyder, James C; Catanese, Anthony J. 1997. Pengantar Arsitektur. Erlangga. Jakarta

Sugiarto, dkk. 2003. Teknik Sampling. PT.Gramedia Pustaka Utama. Jakarta

UIN Alauddin Makassar. 2009. Pedoman Pusat Informasi dan Komputer. UIN Alauddin Makassar. Makassar

Universitas Gadjah Mada. 2011. Peraturan Rektor Universitas Gadjah Mada Nomor 2451/P/SK/KP/2011 tentang Pegawai Khusus Universitas Gadjah Mada. UGM, Yogyakarta

Valera, Sergi. 1998. Public Space and Social Identity. Paper on Ramesar, A Urban Regeneration, A Challenge for Public Art: Universitat de Barcelona. Universitat de Barcelona. Barcelona

White, Edward T. 1992. Buku Sumber Konsep: Sebuah Kosakata BentukBentuk Arsitektural. Intermatra. Bandung

Worpole, Ken; Knox, Katharine. 2007.The Social Values of Public Spaces. Paper on research project under the Joseph Rowntree Foundation. The Homestead, 40 Water End, York YO30 6WP

Zahnd, Markus. 2009. Pendekatan dalam Perancangan Arsitektur: Metode untuk Menganalisis dan Merancang Arsitektur secara Efektif.Penerbit Kanisius, Semarang: Soegijapranata University Press, Yogyakarta 